\title{
POTENSI DAN KEANEKARAGAMAN TUMBUHAN OBAT DI HUTAN KALIMANTAN DAN UPAYA KONSERVASINYA
}

\author{
(Potency and Diversity of Medicinal Plant in Kalimantan \\ Forests and it's Conservation Effort)
}

\author{
Oleh/by : \\ Noorhidayah $^{1}$, Kade Sidiyasa $^{1} \&$ Ibnu Hajar ${ }^{2}$
}

\begin{abstract}
The aims of this paper is to describe the potential of medicinal plant in some selected forest areas in Kalimantan, the utilization and their conservation efforts. It is hoped that it may contribute the conservation policy on medicinal forest plants in Kalimantan. Potential of the medicinal plant in Kalimantan's forest scattered in various forest areas, and it is in high diversity, various life form and uses. There are three main factors that could threaten the sustainable of medicinal plants in Kalimantan, that are destruction of the habitat, scarcity, and over eksploitation. Medicinal plant conservation could be through in-situ and or ex-situ. The in-situ conservation beld by manage the forest area as the natural habitat of the medicinal plants, while the ex-situ conservation bel outside of the native babitats. Wise utilization and research activities are important in conservation of the medicinal plants in Kalimantan.
\end{abstract}

Key word:Medicinalplant, diversity, conservation, Kalimantan,

\begin{abstract}
ABSTRAK
Tujuan penulisan ini adalah untuk menggambarkan potensi tumbuhan obat pada beberapa kawasan hutan di Kalimantan, pemanfaatannya oleh masyarakat secara tradisional dan upaya konservasi yang dapat dilakukan. Tulisan ini diharapkan dapat memberikan masukan untuk kebijakan konservasi tumbuhan obat hutan Kalimantan. Potensi tumbuhan obat hutan Kalimantan tersebar pada berbagai kawasan hutan dengan tingkat keanekaragaman jenis yang tinggi, beragam habitus dan bagian yang dimanfaatkan. Tiga faktor utama yang menjadi ancaman bagi kelestarian tumbuhan obat di kawasan hutan di Kalimantan adalah kerusakan habitat, kelangkaan jenis dan eksploitasi secara berlebihan. Konservasi tumbuhan obat dapat dilakukan secara in-situ dan atau secara ex-situ. Upaya konservasi in-situ dilakukan melalui pengelolaan kawasan hutan yang merupakan habitat alami tumbuhan obat. Sedangkan konservasi ex-situ dilakukan di luar habitat aslinya. Pemanfaatan tumbuhan obat hutan secara bijaksana dan penelitian tumbuhan obat berperan penting bagi upaya konservasi tumbuhan obat hutan Kalimantan.
\end{abstract}

Kata kunci : Tumbuhan obat, keanekaragaman, konservasi, Kalimantan.

\footnotetext{
${ }^{1}$ Loka Penelitian dan Pengembangan Satwa Primata

${ }^{2}$ Fakultas Kehutanan Universitas Mulawarman
} 


\section{J umal AnalisisKedijakan Kehutanan \\ Vol. 3No. 2, J uni 2006: 95- 107}

\section{PENDAHULUAN}

Borneo merupakan pulau ketiga terbesar di dunia yang dikenal sebagai salah satu pusat keanekaragaman tumbuhan dunia. Dengan luas kurang lebih $740.000 \mathrm{~km}^{2}$, di kawasan ini terdapat 10.00012 .000 jenis tumbuhan berbunga atau sekitar 5 - $6 \%$ dari total yang ada di dunia (Merill, 1950; Van Steenis, 1950; Kiew, 1984; Mat Saleh et al., 1992 dalam Soepadmo and Wong, 1995). Sebagian dari jumlah tersebut 40 - 50\% diantaranya merupakan jenis endemik Borneo (Soepadmo and Wong, 1995). Kalimantan merupakan bagian dari pulau Borneo yang berada di Wilayah Negara Kesatuan Republik Indonesia. Kawasan Kalimantan meliputi empat provinsi, yakni Kalimantan Barat, Kalimantan Tengah, Kalimantan Selatan dan Kalimantan Timur. Kawasan ini memiliki luas 539.460 $\mathrm{km}^{2}$ (73\% dari luas pulau Borneo).

Salah satu bentuk pemanfaatan tumbuhan hutan Kalimantan adalah sebagai bahan obat tradisional masyarakat setempat. Potensi tumbuhan obat pada kawasan hutan di Kalimantan cukup beragam, baik yang telah dimanfaatkan oleh masyarakat sekitar kawasan maupun yang belum dimanfaatkan. Suriawiria (2000), mengemukakan bahwa tumbuhan berkhasiat obat adalah tumbuhan yang bagian tertentu atau seluruh bagian dari tumbuhan tersebut diyakini atau dipercaya dapat dimanfaatkan sebagai penghilang rasa sakit atau sebagai salah satu obat penyembuh dari suatu penyakit. Demikian pula definisi dari masyarakat Dayak Benuaq yang disebutkan oleh Amborowati (2002), bahwa tumbuhan obat adalah semua jenis tumbuhan yang dapat digunakan untuk menyembuhkan penyakit manusia, baik secara langsung maupun tidak langsung yang biasanya dilakukan melalui upacara-upacara pengobatan.

Tulisan ini berusaha menjabarkan tentang potensi tumbuhan obat pada kawasan hutan di wilayah Kalimantan, pemanfaatannya oleh masyarakat secara tradisional dan upaya konservasi yang dapat dilakukan. Mengingat laju kerusakan hutan Kalimantan yang cukup tinggi maka upaya konservasi tumbuhan obat yang merupakan bagian dari ekosistem hutan merupakan sesuatu yang penting. Selain itu tumbuhan obat memiliki nilai ekonomi, ekologi dan sosial sehingga dapat menjadi tumbuhan prioritas untuk dikonservasi. Tulisan ini diharapkan dapat memberikan masukan untuk kebijakan konservasi tumbuhan obat hutan Kalimantan

\section{POTENSI TUMBUHAN OBAT DI KAWASAN HUTAN KALIMANTAN}

Dari berbagai penelitian yang dilakukan di kawasan hutan Kalimantan, dapat diketahui bahwa kawasan ini memiliki potensi tumbuhan obat yang beragam. Potensi yang terdata saat ini belum menunjukkan potensi tumbuhan obat Kalimantan secara keseluruhan, tetapi dapat menggambarkan potensi tumbuhan obat pada berbagai kawasan hutan tertentu saja. Potensi tumbuhan obat ini tersebar pada berbagai kawasan hutan baik kawasan konservasi seperti taman nasional, kawasan hutan penelitian, hutan lindung dan kawasan hutan lainnya. [Tabel 1.] 
Tabel1. Tumbuhan obat tercatat pada beberapa kawasan hutan di Kalimantan Table 1. Recordered ofpotentialmedicinal plant in some forest areas in Kalimantan

\begin{tabular}{|c|c|c|c|c|c|c|}
\hline \multirow{2}{*}{ No. } & \multirow{2}{*}{$\begin{array}{l}\text { Kawasan Hutan } \\
\text { (Forest area) }\end{array}$} & \multicolumn{3}{|c|}{$\begin{array}{l}\text { Potensi Tumbuhan Obat } \\
\text { (Potency of medicinal plant) }\end{array}$} & \multirow{2}{*}{$\begin{array}{l}\text { Penelitian/ } \\
\text { sumber } \\
\text { (Sources) }\end{array}$} & \multirow{2}{*}{$\begin{array}{l}\text { Keterangan } \\
\text { (Complement) }\end{array}$} \\
\hline & & $\begin{array}{l}\text { Suku } \\
\text { (Family) }\end{array}$ & $\begin{array}{l}\text { Marga } \\
\text { (Genus) }\end{array}$ & $\begin{array}{l}\text { Jenis } \\
\text { (Species) }\end{array}$ & & \\
\hline 1. & $\begin{array}{l}\text { Taman Nasional } \\
\text { Betung Kerihun } \\
\text { Kalimantan Barat } \\
\text { (Betung Keribun } \\
\text { National Park, } \\
\text { West Kalimantan) }\end{array}$ & 27 & 36 & 41 & $\begin{array}{c}\text { Guntavid et al., } \\
1997\end{array}$ & $\begin{array}{l}\text { Ekosistem } \\
\text { hutan dataran } \\
\text { rendah, } \\
\text { dimanfaatkan } \\
\text { oleh suku } \\
\text { Dayak Iban }\end{array}$ \\
\hline 2. & $\begin{array}{l}\text { Hutan Pendidikan } \\
\text { Hampangen } \\
\text { Kalimantan } \\
\text { Tengah } \\
\text { (Hampangen } \\
\text { Education Forest, } \\
\text { Central } \\
\text { Kalimantan) } \\
\end{array}$ & 25 & 35 & 38 & Ilona, 2003 & $\begin{array}{l}\text { Kawasan } \\
\text { hutan } \\
\text { ekosistem } \\
\text { rawa }\end{array}$ \\
\hline 3. & $\begin{array}{l}\text { Kawasan Malinau } \\
\text { Research Forest } \\
\text { (MRF) CIFOR } \\
\text { Kalimantan Timur } \\
\text { (Malinau Forest } \\
\text { Research area, } \\
\text { East Kalimantan) } \\
\end{array}$ & 61 & 111 & 132 & Rahayu, 2005 & $\begin{array}{l}\text { Dimanfaatkan } \\
\text { oleh } \\
\text { masyarakat } \\
\text { suku Punan } \\
\text { dan Kenyah }\end{array}$ \\
\hline 4. & $\begin{array}{l}\text { Kawasan wisata } \\
\text { alam Sangkima, } \\
\text { Taman Nasional } \\
\text { Kutai, Kalimantan } \\
\text { Timur (Sangkima } \\
\text { Nature Tourism } \\
\text { Area, Kutai } \\
\text { National Park, } \\
\text { East Kalimantan) }\end{array}$ & 27 & 28 & 30 & $\begin{array}{c}\text { Noorhidayah } \\
\text { dan Hajar, } \\
2004\end{array}$ & $\begin{array}{l}\text { Identifikasi } \\
\text { dilakukan di } \\
\text { sepanjang } \\
\text { boardwalk } \\
\text { Sangkima } \\
\text { KTN }\end{array}$ \\
\hline 5. & $\begin{array}{l}\text { Taman Nasional } \\
\text { Kutai Kalimantan } \\
\text { Timur - Daerah } \\
\text { Mentoko } \\
\text { (Kutai National } \\
\text { Park, East } \\
\text { Kalimantan - } \\
\text { Mentoko Area) }\end{array}$ & - & - & 49 & $\begin{array}{c}\text { Balai Taman } \\
\text { Nasional Kutai, } \\
1997\end{array}$ & $\begin{array}{l}\text { Identifikasi } \\
\text { dilakukan } \\
\text { dalam nama } \\
\text { lokal/nama } \\
\text { daerah }\end{array}$ \\
\hline 6. & $\begin{array}{l}\text { Kebun Raya } \\
\text { UNMUL } \\
\text { Samarinda } \\
\text { (UNMUL- } \\
\text { Samarinda } \\
\text { Botanical Garden) }\end{array}$ & 19 & 22 & 24 & Jannah, 2004 & - \\
\hline
\end{tabular}




\begin{tabular}{|c|l|c|c|c|c|l|}
\hline 7. & $\begin{array}{l}\text { Dataran Tinggi } \\
\text { Apo Kayan (Apo } \\
\text { Kayan Plateau) }\end{array}$ & 77 & 165 & 200 & $\begin{array}{c}\text { Leamen et al., } \\
1991\end{array}$ & $\begin{array}{l}\text { Dimanfaatkan } \\
\text { oleh suku } \\
\text { Dayak } \\
\text { Kenyah }\end{array}$ \\
\hline 8 & $\begin{array}{l}\text { Barongtongkok, } \\
\text { Kutai Barat } \\
\text { Kalimantan Timur } \\
\text { (Barongtongkok } \\
\text { area, district of } \\
\text { West Kutai, East } \\
\text { Kalimantan) }\end{array}$ & - & - & 301 & Amborowati, \\
2002 & $\begin{array}{l}\text { Dimanfaatkan } \\
\text { oleh suku } \\
\text { Dayak } \\
\text { Benuaq. } \\
\text { Identifikasi } \\
\text { dilakukan } \\
\text { dalam nama } \\
\text { lokal/nama } \\
\text { daerah }\end{array}$ \\
\hline
\end{tabular}

Jenis-jenis tumbuhan obat yang berhasil diidentifikasi dan didokumentasikan melalui berbagai penelitian tersebut merupakan jenis-jenis yang secara tradisional telah dimanfaatkan oleh masyarakat lokal. Bahkan beberapa penelitian mengkaji etnobotani suku tertentu di Kalimantan termasuk pemanfaatan tumbuhan untuk pengobatan. Ada kecenderungan bahwa jenis-jenis tumbuhan obat yang ada di kawasan hutan di Kalimantan merupakan jenis-jenis yang dimanfaatkan oleh suku-suku yang menghuni sekitar kawasan tersebut. Sebagai contoh suku Dayak Iban memanfaatkan jenis-jenis tumbuhan di kawasan Taman Nasional Betung Kerihun Kalimantan Barat, suku Dayak Punan dan Kenyah memanfaatkan jenis-jenis tumbuhan di wilayah Malinau, suku Dayak Benuaq di Barongtongkok, Kutai Barat dan suku Dayak Kenyah di dataran tinggi Apo Kayan.

Dari segi pemanfaatan, berbagai jenis tumbuhan obat di hutan Kalimantan ini memiliki keampuhan sendiri-sendiri dan berpotensi yang besar untuk dikembangkan. [Tabel 2.]

\section{KEANEKARAGAMAN TUMBUHAN OBAT DI KAWASAN HUTAN KALIMANTAN}

\section{A. Keanekaragaman Habitus}

Tumbuhan obat di hutan Kalimantan tidak hanya berupa tumbuhan berkayu, tetapi juga tumbuhan tidak berkayu dengan berbagai habitus, yakni berupa pohon, perdu, terna/herba, liana dan paku (Tabel1).

Habitus tumbuhan obat di Kebun Raya Universitas Mulawarman (UNMUL) Samarinda lebih beragam (6 macam habitus) dibandingkan dengan kawasan lainnya.

Tabel 3 menunjukkan bahwa tumbuhan obat pada kawasan hutan di Kalimantan paling banyak memiliki habitus pohon dan perdu. Di sepanjang boardwalk Sangkima dan Kebun Raya Universitas Mulawarman (UNMUL) Samarinda memiliki jumlah tumbuhan berkhasiat obat paling banyak berhabitus pohon (masing-masing $52 \%$ dan $42 \%$ ). Sedangkan ditempat lain umumnya yang paling banyak adalah perdu. 
Tabe12. Jumlah jenis penyakit dan tumbuhan pada beberapa kawasan hutan di Kalimantan

Table 2. Estimate number of deseases and medicinal plants in some forest area in Kalimantan

\begin{tabular}{|c|c|c|c|}
\hline No & $\begin{array}{l}\text { Kawasan hutan } \\
\text { (Forest area) }\end{array}$ & $\begin{array}{c}\text { Jumlah kelompok } \\
\text { penyakit yang dapat } \\
\text { diobati } \\
\text { (The total of illnesses } \\
\text { group which is } \\
\text { remedied) }\end{array}$ & $\begin{array}{l}\text { Jumlah jenis penyakit } \\
\text { yang dapat diobati } \\
\text { (The total of illnesses } \\
\text { which is remedied) }\end{array}$ \\
\hline 1 & $\begin{array}{l}\text { Taman Nasional Betung } \\
\text { Kerihun Kalimantan Barat. } \\
\text { (Betung Keribun National } \\
\text { Park, West Kalimantan) }\end{array}$ & $\mathrm{na} / \mathrm{tad}$ & 32 \\
\hline 2 & $\begin{array}{l}\text { Hutan Pendidikan } \\
\text { Hampangen Kalimantan } \\
\text { Tengah (Hampangen } \\
\text { Education Forest, Central } \\
\text { Kalimantan) }\end{array}$ & 9 & 58 \\
\hline 3 & $\begin{array}{l}\text { Kawasan Malinau Research } \\
\text { Forest (MRF) CIFOR } \\
\text { Kalimantan Timur } \\
\text { (Malinau Forest Research } \\
\text { area, East Kalimantan) }\end{array}$ & 14 & 92 \\
\hline 4 & $\begin{array}{l}\text { Kawasan wisata alam } \\
\text { Sangkima, Taman Nasional } \\
\text { Kutai, Kalimantan Timur } \\
\text { (Sangkima Nature Tourism } \\
\text { Area, Kutai National Park, } \\
\text { East Kalimantan) }\end{array}$ & $\mathrm{na} / \mathrm{tad}$ & 53 \\
\hline 5 & $\begin{array}{l}\text { Taman Nasional Kutai } \\
\text { Kalimantan Timur - Daerah } \\
\text { Mentoko (Kutai National } \\
\text { Park, East Kalimantan - } \\
\text { Mentoko Area ) }\end{array}$ & $\mathrm{na} / \mathrm{tad}$ & 42 \\
\hline 6 & $\begin{array}{l}\text { Kebun Raya UNMUL } \\
\text { Samarinda (UNMUL- } \\
\text { Samarinda Botanical } \\
\text { Garden) }\end{array}$ & $\mathrm{na} / \mathrm{tad}$ & 47 \\
\hline 7 & $\begin{array}{l}\text { Dataran Tinggi Apo Kayan } \\
\text { (Apo Kayan Plate au) }\end{array}$ & 18 & $\mathrm{na} / \mathrm{tad}$ \\
\hline
\end{tabular}

Keterangan $($ Remark $): \mathrm{na} / \mathrm{tad}=$ data tidak tersedia (no data available) 
Tabel 3. Habitus dan distribusi tumbuhan obat di beberapa wilayah hutan Kalimantan

Table 3. Distribution and habitus of medicinal forest plant at some forest area in Kalimantan

\begin{tabular}{|l|c|c|c|c|c|}
\hline \multirow{1}{*}{$\begin{array}{c}\text { Habitus } \\
\text { (Lifeform) }\end{array}$} & \multicolumn{5}{|c|}{$\begin{array}{c}\text { Distribusi tumbuhan obat } \\
\text { Distribution of medicinal plant across } \\
\text { and habitus) } \% \text { selected research area }\end{array}$} \\
\cline { 2 - 6 } & $\begin{array}{c}\text { Sepanjang } \\
\text { Boardwalk } \\
\text { Sangkima, } \\
\text { TNK }\end{array}$ & $\begin{array}{c}\text { Hutan } \\
\text { Pendidikan } \\
\text { Hampangen }\end{array}$ & $\begin{array}{c}\text { Mentoko, } \\
\text { TNK }\end{array}$ & $\begin{array}{c}\text { Malinau } \\
\text { Research } \\
\text { Forest } \\
\text { (MRF) }\end{array}$ & $\begin{array}{c}\text { Kebun } \\
\text { Raya } \\
\text { UNMUL } \\
\text { Samarinda }\end{array}$ \\
\hline Pohon (Tree) $)$ & 52 & 34 & 20 & 20 & 42 \\
\hline $\begin{array}{l}\text { Perdu/semak } \\
\text { (Shrub) }\end{array}$ & 24 & 40 & 46 & 46 & 4 \\
\hline $\begin{array}{l}\text { Liana/Pemanjat } \\
\text { (Liana/climber })\end{array}$ & 10 & 16 & 16 & 16 & 4 \\
\hline $\begin{array}{l}\text { Herba/terna } \\
\text { (Herb) }\end{array}$ & 7 & 5 & 18 & 18 & 38 \\
\hline Paku (Fern) & 7 & $\mathrm{na} / \mathrm{tad}$ & $\mathrm{na} / \mathrm{tad}$ & $\mathrm{na} / \mathrm{tad}$ & $\mathrm{na} / \mathrm{tad}$ \\
\hline $\begin{array}{l}\text { Jamur } \\
\text { (mushroom) }\end{array}$ & $\mathrm{na} / \mathrm{tad}$ & 5 & $\mathrm{na} / \mathrm{tad}$ & $\mathrm{na} / \mathrm{tad}$ & $\mathrm{na} / \mathrm{tad}$ \\
\hline $\begin{array}{l}\text { Bambo } \\
\text { (Bamboo })\end{array}$ & $\mathrm{na} / \mathrm{tad}$ & $\mathrm{na} / \mathrm{tad}$ & $\mathrm{na} / \mathrm{tad}$ & $\mathrm{na} / \mathrm{tad}$ & 4 \\
\hline Epifit (Epiphyte $)$ & $\mathrm{na} / \mathrm{tad}$ & $\mathrm{na} / \mathrm{tad}$ & $\mathrm{na} / \mathrm{tad}$ & $\mathrm{na} / \mathrm{tad}$ & 8 \\
\hline
\end{tabular}

Keterangan $($ Remark $):$ na/tad $=$ data tidak tersedia $($ no data available $)$

\section{B. Keanekaragaman Bagian Tumbuhan yang Digunakan Sebagai Obat}

Seringkali hanya bagian tertentu saja dari tumbuhan obat yang dapat digunakan dalam pengobatan, tetapi dapat juga seluruh bagian tumbuhan bermanfaat dalam pengobatan. Bagian tumbuhan yang dapat digunakan dalam pengobatan antara lain akar, batang, kulit, daun bunga, buah dan sarinya. [Gambar 1, 2, 3 dan 4].

Diantara jenis-jenis tumbuhan obat tersebut ada beberapa jenis yang beberapa bagian tumbuhannya dapat dimanfaatkan untuk pengobatan, mulai dari kulit, batang, daun getah dan akar. Jenis-jenis tersebut antara lain Alstonia scholaris (pulai), Aquilaria malaccensis (gaharu), Cananga odorata (Kenanga), Durio zibethinus (durian), Eusideroxylon zwageri (ulin), Octomeles sumatrana (benuang bini) dan Syzygium polyanthum (salam). Akan tetapi khasiat dari bagian-bagian tersebut sering kali juga berbeda. sedangkan jenisjenis tumbuhan yang hanya memiliki satu bagian tertentu saja yang dapat digunakan dalam pengobatan antara lain adalah Asplenium nidus (palam sarag) (daun), Imperata cylindrica (alang-alang) (rimpang), Zalacca edulis (salak) (biji), dan Baubinia tomentosa (akar kupu-kupu) (daun). 


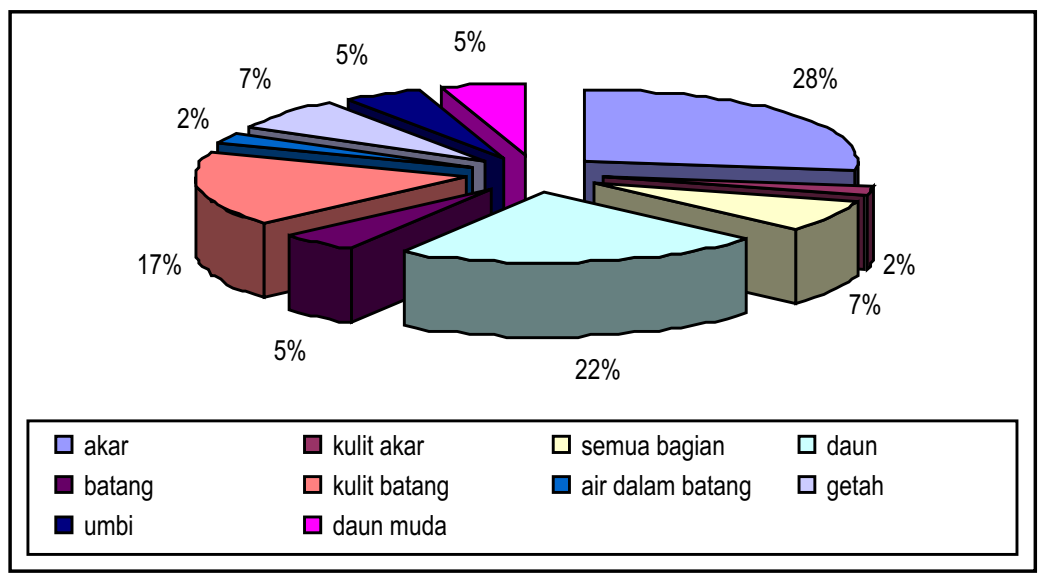

Gambar 1. Keanekaragaman tumbuhan obat di kawasan Hutan Pendidikan Hampangen Kalimantan Tengah

Figure 1. Diversity of medicinalplant in Hampangen Education Forest, Central Kalimantan

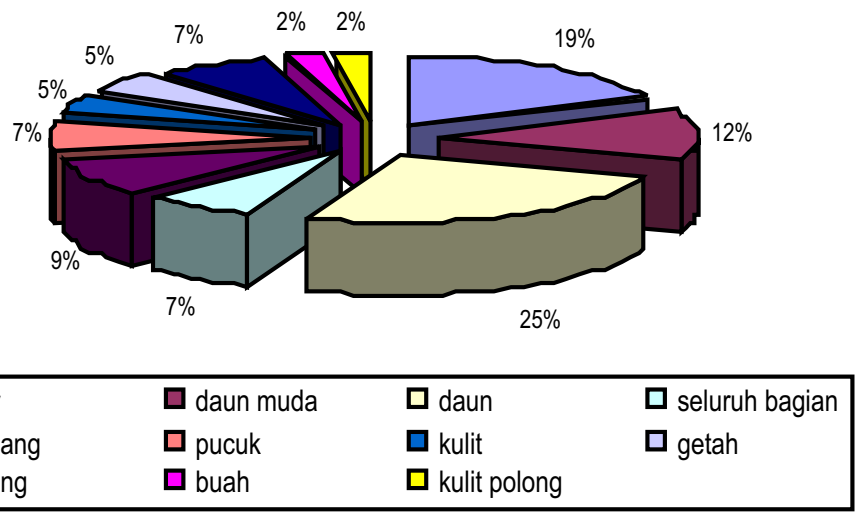

Gambar2. Keanekaragaman tumbuhan obat di Taman Nasional Betung Kerihun, Kalimantan Barat

Figure 2. $\quad$ Diversity of medicinalplant in Betung Keribun NationalPark, West Kalimantan 


\section{J umal AnalisisKedijakan Kehutanan}

Vol. 3No. 2, J uni 2006: 95- 107

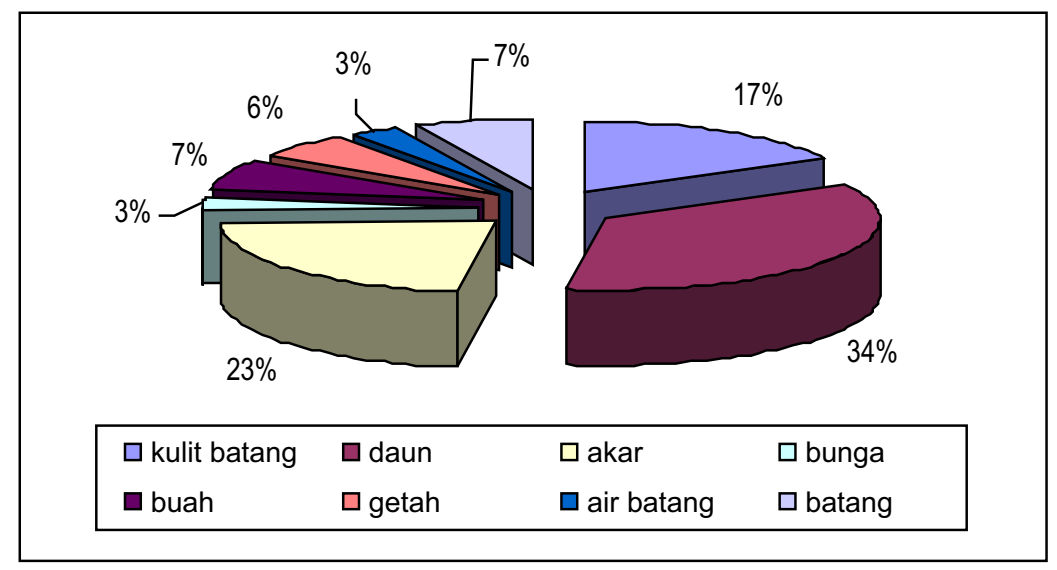

Gambar 3. Keanekaragaman tumbuhan obat di Mentoko, Taman Nasional Kutai, Kalimantan Timur

Figure 3. Diversity of medicinalplant in Mentoko, Kutai NationalPark, East Kalimantan

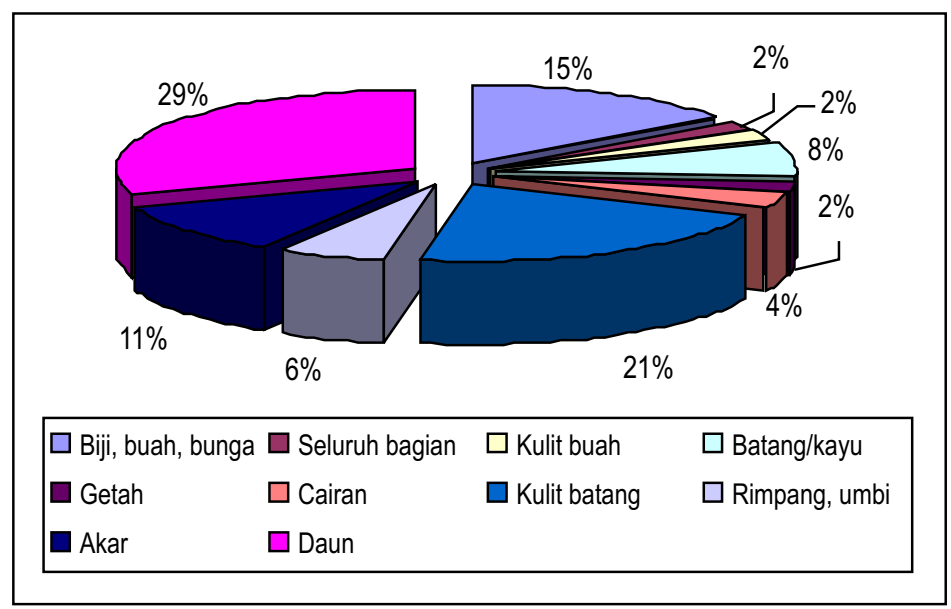

Gambar4. Keanekaragaman tumbuhan obat di Taman Nasional Kutai (Sepanjang Boardwalk Sangkima), Kalimantan Timur

Figure 4. Diversity of medicinal plant along the Sangkima Boardwalk, Kutai National Park, East Kalimantan 


\section{Potensi dan Keandkaraganan Tumbuhan Obat ........ Norhidaych, KadeSidiyasa dan I bnu Hajar}

Gambar 1 sampai dengan Gambar 4 menunjukkan bahwa daun merupakan bagian tumbuhan yang paling banyak digunakan untuk pengobatan. Hal ini dapat dipahami karena daun merupakan bagian tumbuhan yang paling mudah dijumpai, dipetik/diambil, dalam jumlah banyak dan tersedia sepanjang tahun. Selain itu mungkin daun merupakan bagian yang paling mudah untuk diolah atau diramu.

Tingginya pemanfaatan daun ini merupakan satu bentuk kearifan masyarakat yang baik karena dengan memanfaatkan daun saja tidak terlalu mengganggu pertumbuhan tumbuhan. Pemanfaatan daun sebagai bahan obat dalam jumlah tertentu tidak akan mengganggu pertumbuhan tumbuhan secara nyata. [Noorhidayah dan Sidiyasa (2005)] Bagian-bagian lainnya seperti kulit, akar, batang, dan umbi agak sulit untuk dimanfaatkan. Dan bahkan pemanfaatan bagian ini selain berpengaruh nyata terhadap pertumbuhan, juga akan mematikan. Sementara bagian biji, bunga dan buah merupakan bagian-bagian yang hanya dapat dijumpai pada musim tertentu saja.

\section{KONSERVASI TUMBUHAN OBAT DI KALIMANTAN}

\section{A. Ancaman terhadap Kelestarian Tumbuhan Obat}

Faktor utama yang menjadi ancaman bagi kelestarian tumbuhan obat di hutan Kalimantan secara umum dapat dikelompokkan menjadi tiga, yaitu kerusakan habitat, kelangkaan jenis dan pemanfaatan sumberdaya hutan secara berlebihan.

Kerusakan habitat merupakan faktor yang cukup signifikan mengancam kelestarian tumbuhan obat. Rusaknya habitat akan menyebabkan terganggunya pertumbuhan jenis-jenis tumbuhan obat tersebut. Bahkan kerusakan habitat ini dapat secara langsung menyebabkan kemusnahan. Kebakaran hutan, penebangan liar dan konversi lahan hutan menjadi lahan non kehutanan merupakan penyebab terjadinya kerusakan habitat. Keanekaragaman tumbuhan Kalimantan yang besar terancam oleh adanya aktivitas pemanfaatan sumberdaya hutan yang berlebihan. [Witono (2005)] Pada tahun 1968, diperkirakan luas hutan Kalimantan 77\% dari luas daratan. Tahun 1984 menurun menjadi 73\% dari luas daratan dan pada tahun 1990 luas hutan berkurang lagi menjadi 63\%. Berkurangnya areal hutan di Kalimantan akan diikuti dengan berkurangnya populasi maupun keanekaragaman jenis tumbuhan. [Witono (2005)] .

Faktor lain yang menjadi ancaman bagi kelestarian tumbuhan obat di kawasan hutan di Kalimantan adalah kelangkaan jenis. Beberapa jenis tumbuhan obat merupakan jenis-jenis yang sudah sedikit di alam dan cenderung langka. Jenis-jenis tumbuhan obat hutan yang sudah tergolong langka dan dilindungi undang-undang maupun CITES antara lain : ulin (Eusideroxylon zwager), kantong semar (Nepenthes reinwartiana), ramin (Gonystylus bancanus) dan gaharu (Aquilaria malaccensis).

Selain itu beberapa jenis tumbuhan juga masuk dalam Appendix CITES (Convention on International Trade of Endangered Species) baik pada kategori Appendiks II mapun Appendiks III. Aquilaria malaccensis masuk dalam Apendiks II CITES (dijumpai di TNK), Gonystylus bancanus masuk dalam Apendiks II CITES (dijumpai di Hutan Pendidikan Hampangen Kalimantan Tengah) dan Nepenthes reinwardtiana masuk dalam Apendiks II CITES. 


\section{J umal AnalisisKedijakanKehutanan Vol. 3No. 2, J uni 2006: 95- 107}

Pemanfaatan berlebihan terhadap jenis tumbuhan obat yang telah teridentifikasi dari hutan juga merupakan ancaman bagi kelestarian tumbuhan obat di Kalimantan. Hal ini terjadi karena jenis-jenis tersebut umumnya belum dibudidayakan secara luas. [Zuhud et al., (1994)] Pemanenan tumbuhan obat langsung dari alam apabila dilakukan tanpa memperhatikan kelestarian dapat menyebabkan kelangkaan dan akhirnya kepunahan. Selain itu pemanfaatan jenis-jenis pohon yang memiliki khasiat obat tetapi juga memiliki nilai komersial dapat merupakan ancaman kelestarian tumbuhan obat di alam, misalnya ulin (Eusideroxylon zwager), Benuang Bini (Octomeles sumatrana) dan Bayur (Pterospermum javanicum). Dengan demikian agar kelestariannya terjamin maka diperlukan upaya konservasi. secara in-situ maupun ex-situ.

Rahayu (2005) menyebutkan dua jenis tumbuhan obat yang menjadi prioritas dalam upaya pelestarian pemanfaatannya di Kawasan Hutan Malinau Research Forest, Kalimantan Timur yaitu Litsea cubeba (suku Lauraceae) dan Eurycoma longifolia (suku Simaroubaceae). Beberapa jenis tumbuha obat juga merupakan jenis tumbuhan dilindungi berdasarkan UU No.5 tahun 1990 tentang konservasi sumberdaya hayati dan ekosistemnya.

\section{B. Konservasi Tumbuhan Obat Secara In-situ dan Ex-situ}

Konservasi tumbuhan obat hutan dapat dilakukan secara in-situ pada kawasankawasan hutan, baik di kawasan hutan konservasi, hutan lindung, hutan produksi dan hutan lainnya. Upaya konservasi in-situ ini dilakukan dengan cara mengelola secara baik kawasan-kawasan hutan yang merupakan habitat asli dari tumbuhan obat yang bersangkutan. Dengan adanya kegiatan pengelolaan kawasan terutama perlindungan maka berarti pula memberikan perlindungan terhadap tumbuhan obat yang ada didalamnya.

Pada kawasan konservasi upaya konservasi diharapkan dapat menjadi lebih efektif karena adanya pengelolaan yang jelas oleh pihak berwenang. Di kalimantan terdapat 44 kawasan konservasi yang terdiri dari (delapan) kawasan Taman Nasional, 15 Kawasan Cagar Alam, (empat) Kawasan Suaka Margasatwa, 14 Kawasan Taman Wisata Alam, (dua) Kawasan Taman Hutan Raya dan (satu) Arboretum.

Peningkatan pengelolaan kawasan konservasi di Kalimantan merupakan salah satu cara untuk mengkonservasi tumbuhan obat hutan yang ada didalamnya. Hal ini mencakup kegiatan identifikasi dan inventarisasi tumbuhan obat hutan di kawasan konservasi, pengelolaan habitat tumbuhan obat hutan, monitoring, pemanfaatan secara bijaksana, serta perlindungan dan pengamanan.

Konservasi ex-situ merupakan kegiatan perlindungan yang dilakukan diluar habitat asli dari suatu janis tumbuhan atau satwa. Konservasi ex-situ merupakan tindakan yang secara langsung dilakukan pada jenis-jenis tumbuhan obat hutan yang akan dikonservasi. Upaya ini juga dapat dikatakan sebagai tindakan domestikasi tumbuhan sehingga pada akhirnya dapat dibudidayakan secara luas (Leakey and Newton, 1994).

Budidaya tumbuhan obat asal hutan dapat dikatakan sebagai salah satu upaya konservasi ex-situ. Upaya budidaya ini juga diperlukan mengingat tumbuhan obat memiliki prospek yang baik untuk dikembangkan. Salah satu kendala dalam pengembangan 


\section{Potensi dan Keandkaraganan Tumbuhan Obat ........ Noorhidaych, KadeSidyesa dan I bnu Hajar}

tumbuhan obat Indonesia adalah ketidakstabilan produksi atau keberlangsungan produksi bahan obat asal tumbuhan yang tidak terjamin (Kulsum dan Gusmailina, 2003). Dengan demikian budidaya tumbuhan asal hutan diharapkan dapat menjamin keberlangsungan ketersediaan bahan obat yang berasal dari tumbuhan hutan.

\section{Pemanfaataan Tumbuhan Obat Hutan Secara Bijaksana}

Mengkonservasi suatu jenis tumbuhan termasuk yang berkhasiat obat bukan berarti menutup aspek pemanfaatan dari jenis-jenis tersebut. Upaya konservasi mencakup tindakan perlindungan, pemanfaatan dan penelitian. Pemanfaatan jenis-jenis tumbuhan obat hutan secara bijaksana dapat dikatakan sebagai upaya konservasi tumbuhan obat hutan. Adapun yang dimaksud dengan pemanfaatan secara bijaksana adalah pemanfaatan yang disesuaikan dengan kemanpuan suatu jenis tumbuhan untuk berregenerasi. [Zuhud et al., (1994)]

\section{Penelitian dan Pengembangan Tumbuhan Obat Asal Hutan}

Penelitian dan pengembangan tumbuhan obat asal hutan ini mencakup penelitian yang terkait dengan upaya konservasi in-situ dan ex-situ, inventasisasi potensi tumbuhan obat hutan, identifikasi jenis dan kandungan kimia (kandungan bahan obat), teknik budidaya, pemanfaatan tumbuhan obat oleh masyarakat dan pengetahuan tradisional masyarakat, pemasaran, teknologi pengembangan dan industri tumbuhan obat hutan. Upaya ini sangat penting artinya bagi pelestarian dan pengembangan tumbuhan obat hutan Kalimantan.

\section{PENUTUP}

Kawasan hutan di Kalimantan memiliki potensi tumbuhan obat dengan beragam habitus dan bagian yang dapat dimanfaatkan. Potensi ini membuka peluang untuk dikembangkan bagi kesejahteraan masyarakat dan kemajuan ilmu pengetahuan dan teknologi. Hanya saja ada tiga faktor utama yang menjadi ancaman bagi kelestarian tumbuhan obat di kawasan hutan di Kalimantan, yaitu kerusakan habitat, kelangkaan jenis dan eksploitasi secara berlebihan.

Konservasi tumbuhan obat hutan dapat dilakukan secara in-situ maupun ex-situ. Selain itu pemanfaatan tumbuhan obat hutan secara bijaksana juga merupakan bagian dari upaya konservasi. Penelitian tumbuhan obat juga memegang peranan penting bagi upaya konservasi tumbuhan obat hutan Kalimantan.

\section{DAFTAR PUSTAKA}

Amborowati, A. 2002. Budidaya dan Pemanfaatan Tumbuhan Obat oleh Masyarakat Dayak Benuaq di Tepulang Kecamatan Damai Kabupaten Kutai Barat. Fakultas Kehutanan Universitas Mulawarman. Samarinda. Skripsi (Tidak dipublikasikan) 


\section{Jumal Analisis Kedijakan Kehutanan \\ Vd. 3Na 2, Juni 2006: 95- 107}

Balai Taman Nasional Kutai. 1997. Laporan Hasil Pengkajian, Pengembangan dan Pemanfaatan Tumbuhan Obat di Mentoko Taman Nasional Kutai. Bontang.

Guntavid, J. P., L. C. J. Julaihi and Supardiyono. 1997. Ethnobotany. Dalam: Kuswanda, M. P. Chai and I. N. S. Jaya (eds.) IT'TO Borneo Biodiversity Expedition 1997 Scientific Report. Collaboration between the Governments of Indonesia and Malaysia and International Tropical Timber Organization (ITTO). Yokohama, Japan.

Ilona, M. 2003. Analisis, Identifikasi dan Karakteristik Tumbuhan Obat di Hutan Pendidikan Hampangen Universitas Palangkaraya Kalimantan Tengah. (Tesis) Program Pascasarjana Universitas Mulawarman. Samarinda

Jannah, U. N. 2004. Inventarisasi Jenis-Jenis Tumbuhan Berkhasiat Obat di Kebun Raya UNMUL Samarinda. Fakultas Kehutanan Universitas Mulawarman. Samarinda. Skripsi (Tidak dipublikasikan).

Kulsum, U. dan Gusmailina. 2003. Tanaman Obat Asal Hutan sebagai Komoditi Hasil Hutan Bukan Kayu (HHBK) Potensial (Bagian 1). Info Hasil Hutan Vol. 10 No.2. Hal 83 96. Pusat Penelitian dan Pengembangan Teknologi Hasil Hutan. Bogor.

Leakey, R.R.B. and A. C. Newton. 1994. Domestication of Tropical Trees For Timber and non-Timber Products. United Nations Educational, Scientific and Cultural Organization. Paris, France.

Leaman, D. J., R. Yusuf and H. Sangat-Roemantyo. 1991. Kenyah Dayak Forest Medicines. World Wide Fund for Nature Indonesia Programme. Jakarta.

Noorhidayah dan K. Sidiyasa. 2005. Keanekaragaman Tumbuhan Berkhasiat Obat di Taman Nasional Kutai, Kalimantan Timur. Jurnal Analisis Kebijakan Kehutanan Vol. 2 No. 2. Hal. 115-128. Badan Penelitian dan Pengembangan Kehutanan. Jakarta.

dan I. Hajar. 2004. Keanekaragaman Tumbuhan Berkhasiat Obat sepanjang Boardwalk Sangkima Taman Nasional Kutai Kalimantan Timur. Jurnal Ilmiah Kehutanan Rimba Kalimantan. Vol. 9 No. 2. Hal. 40-46. Fakultas Kehutanan Universitas Mulawarman. Samarinda.

Rahayu, Y. D. 2005. Kajian Potensi Tumbuhan Obat di Kawasan Malinau Research Forest (MRF) CIFOR Kabupaten Malinau Kalimantan Timur. (Tesis) Program Pascasarjana Universitas Mulawarman. Samarinda.

Soepadmo, E. and K.M. Wong. 1995. Tree Flora of Sabah and Sarawak (Volume one). A joint publication of Sabah Forestry Department, Malaysia, Forest Research Institute Malaysia and Sarawak Forestry Department, Malaysia. Kuala Lumpur. 


\section{Potensi dan Keandkaraganan Tumbuhan Obat Noorhidaych, KadeSidyesa dan I bnu Hajar}

Suriawiria, U. 2000. Obat Mujarab dari Pekarangan Rumah. Penerbit Papas Sinar Sinanti. Jakarta.

Witono, J. R. 2005. Keanekaragaman Palem (Palmae) di Gunung Lumut Kalimantan Tengah. Biodiversitas (Jounal of Biological Diversity) Vol. 6 Nomor 1. Hal. 22 30. Jurusan Biologi FMIPA Universitas Sebelas Maret, Surakarta.

Zuhud, E. A. M., Ekarelawan dan S. Riswan. 1994. Hutan Tropika Indonesia sebagai Sumber Keanekaragaman Plasma Nutfah Tumbuhan Obat. Dalam: Zuhud, E. A. M. dan Haryanto (eds). Pelestarian pemanfaatan Keanekaragaman Tumbuhan Obat Hutan Tropika Indonesia. Jurusan Konservasi Sumberdaya Hutan Fakultas Kehutanan IPB dan Lembaga Alam Tropika Indonesia (LATIN). Bogor. 